\title{
The Decolonization of Bolivia's Antinarcotics Policy
}

\author{
Alba Hesselroth \\ Independent scholar
}

\begin{abstract}
This paper argues that a peculiar form of colonization developed during the $20^{\text {th }}$ century in Bolivia's antinarcotics policy, comprised of features that resemble both external and internal colonialism. On the one hand, international institutions and the United States were able to impose a system of control and prohibition on the growing and consumption of coca leaf in the country. On the other hand, the governing elite supported by the US imposed their power and domination over coca farmers, introducing US-sponsored prohibition of the growing of coca leaf and promoting forced coca eradication, severely jeopardizing coca farmers' rights. In contrast to previous administrations that passively accepted decisions taken in international forums regarding coca leaf classification as an illegal drug, and rigorously followed instructions issued by the US with respect to eradication of coca, the government of Evo Morales is acting to change this situation in a twofold effort in both international and national arenas. Through the analysis of policies issued by this government between 2006-2014, this paper argues that in its management of antinarcotics policy is pursuing a particular process of decolonization to defend traditional uses of coca leaf, protect social, economic and cultural rights of Andean indigenous peoples involved in its production and/or consumption, and promote economic development of areas where coca is grown.
\end{abstract}

Keywords

Andean countries, decolonization, drug policy, US drug policy 


\section{Resumen}

Este artículo sostiene que, en el siglo XX, se desarrolló una forma peculiar de colonización en la política antinarcótica de Bolivia, compuesta por rasgos parecidos a los del colonialismo externo e interno. Por una parte, las instituciones internacionales y los Estados Unidos lograron imponer en el país un sistema de control y prohibición del cultivo y consumo de la hoja de coca. Por otra parte, la élite gobernante apoyada por los EE.UU. impuso su poder y dominio sobre los cocaleros al introducir esta prohibición y promover la erradicación forzosa de la coca con el auspicio de EE.UU., poniendo en severo peligro los derechos de los cocaleros. A diferencia de anteriores gobiernos que aceptaron pasivamente las decisiones tomadas en foros internacionales acerca de la clasificación de la hoja de coca como droga ilegal y siguieron con rigor las instrucciones de los EE.UU. acerca de la erradicación de la coca, el gobierno de Evo Morales está actuando para cambiar la situación en un doble esfuerzo internacional y nacional. Analizando las políticas de este gobierno entre 2006-2014, este artículo sostiene que en el manejo de la política antinarcótica está siguiendo un proceso particular de descolonización para defender los usos tradicionales de la hoja de coca y proteger los derechos sociales, económicos y culturales de las poblaciones andinas involucradas en su producción y/o consumo, y promover el desarrollo económico de las áreas donde se cultiva.

\section{Palabras claves}

descolonización, países andinos, política antinarcóticos, política antinarcóticos de EE.UU.

The administration of President Evo Morales has not formally included government agencies in charge of implementing the process of decolonization under the scope of Bolivia's antinarcotics policy. Neither the Vice Ministry of Decolonization nor other agencies with specific mandates on decolonization have any attribution regarding antinarcotics policies. Moreover, the Morales government has specifically stated that decolonization is one of the main pillars in the promotion of gender equality (Decreto Supremo 29850) and human rights (Decreto Supremo 29851). Likewise, the Constitution of 2009 and the new Law of Education (Law 070) stipulate the decolonization of the education system. In contrast, no specific statements concerning decolonization have been issued for the area of antinarcotics policy. 
Given this scenario, is it pertinent to talk about the decolonization of Bolivia's antinarcotics policy? This article attempts to show that it is not only relevant but also necessary to do so. First, although the Morales government has not formally established decolonization as a fundamental goal in its antinarcotics policy, in practice the government's management of this policy area largely mirrors the strategies and objectives envisioned in the general framework of decolonization set in Bolivia's National Plan of Development established in 2007, and in the Constitution of 2009. Second, the analysis of Bolivia's antinarcotics policy under the colonization/decolonization framework provides a useful lens to observe not only the content of the national and international regulations that for decades prevailed in this policy area, but also the complexity of the context amid which these were formulated, characterized by international and domestic structural relations of power and domination fueled by the discrimination and inequities pervading within the Bolivian setting. This exercise is necessary in order to understand why and how the antinarcotics regulations were formulated, and the main foreign and national actors and interests behind those regulations. It permits to see particular dynamics and problems prevailing in the Bolivian context and thus, to explore the suitability of the policies issued to confront them.

Since the mid-twentieth century until the year 2006, a peculiar form of colonization developed in Bolivia's antinarcotics policy. It comprised features of both external and internal colonialism, operating simultaneously and reinforcing each other. The dismantling of those colonial features required a process of decolonization that included specific strategies not necessarily viable in other policy areas, and simultaneous efforts of negotiation at both the national and international arenas. The Morales government has initiated this process in contrast to other administrations that focused only on reducing coca production, without solving domestic problems fueling that production, and without tackling bilateral and multilateral issues that determined the continuation of those problems.

The first section of this article refers to the concept of colonialism and its application in the Bolivian case, specifically in the area of antinarcotics policy. To illustrate my contention about the peculiar form of colonialism that developed in this policy area, I describe crucial events during the period 19712005 that reflect the marked influence of the United States in Bolivia's antinarcotics policy, the role that the Bolivian governing criollo elite played in this respect, and how these interactions negatively affected the security of the coca farmers. The second section refers to the concept of decolonization. I outline the diverse notions of decolonization embraced by indigenous 
intellectuals and unions on the one hand, and the particular way in which the Morales administration and the coca farmers interpret decolonization, on the other hand. The third section describes the process of decolonization in Bolivia's antinarcotics policy, its peculiar characteristics, and the Morales administration's main achievements and shortcomings in this area.

\section{Colonialism in Bolivia’s Antinarcotics Policy}

\section{Latin American Perspectives on Internal Colonialism}

In the 1960s, social scientists began to use the concept "internal colonialism" to describe the paradoxical situation in some "independent" states where ample sectors of the population still lived under colonial structures. In Latin America, Mexican sociologists Pablo González Casanova and Rodolfo Stavenhagen were the first and most important intellectuals among those who dealt with the problem systematically (Quijano 577; Rivera, 2010, 66). Their analyses were supplemented in the 1990s by Peruvian sociologist Anibal Quijano who developed the coloniality of power approach. The common idea shared by these scholars is that the structure of subjugation and power based on Eurocentrism, racism and discrimination that Iberian monarchies had established during the colonial era, continued after independence in the form of internal colonialism driven by elites of European ascendance (González 200; Quijano 565-570). White elites took control of the newly-formed independent states, imposed a system of domination and exploitation against Indian and Afro populations, and promoted European epistemologies of race, development, progress, and modernity (Stavenhagen 66-67).

Analyses focused on Bolivia explain that independence from Spain in 1825 never amounted to liberation for the indigenous population. During the Republican era the criollos (descendents of Europeans) repeated the wrongdoings of the former colonial power and postponed the independence of indigenous peoples. For indigenous intellectual Fausto Reinaga, since 1825 there were "two Bolivias": one the oppressor, the Europeanized Bolivia, and the other the slave, the Indian Bolivia (163-171). In 1973, the Kataristas, a movement of Aymara university students and rural leaders, launched the Tiwanaku manifesto denouncing the unjust social, economic, and political system that having been built on ideas and methods imported from abroad, had kept Aymaras and Quechuas as the most exploited stratum in the social 
pyramid. Later, sociologist René Zavaleta, proposed the concept sociedad abigarrada to define the complex Bolivian society in which incomplete capitalist social structures coexist with social and juridical structures proper of pre-capitalism, and the permanent exploitation of Indians by the white dominant caste whose belief in its own superiority was non-negotiable (87). Silvia Rivera Cusicanqui explains that despite cycles of liberalism and populism, colonial structures remained in the stratification of the society and in mechanisms of exclusion-segregation that have been the basis of structural violence and domination in contemporary Bolivia $(2012,45)$. The Revolution of 1952 issued the Agrarian Reform and returned lands to indigenous peoples, but its goals were truncated by the imposition of an unfair tutelage that mimicked colonial era practices (Rivera Cusicanqui 2012, 183). For political scientist Luis Tapia, during the neoliberal period the dismantling of the state through privatizations invigorated the colonial component of Bolivia's politics (58).

\section{External and Internal Colonialism in Bolivia's Antinarcotics Policy}

Taking into account both the submissive stance adopted by Bolivian administrations regarding US foreign drug policy, and the national and international antinarcotics regulations applied in Bolivia during 1971-2005, it is possible to identify in this policy area features typical of external and internal colonialism. There is just one caveat. External colonialism during the Viceroyal era (1532-1825) and internal colonialism during the Republican era (1825onwards) occurred consecutively. In contrast, in the $20^{\text {th }}$ century a contemporary sort of colonialism developed in Bolivia's antinarcotics policy. It simultaneously comprised both external and internal colonialism which remained intrinsically linked until 2005.

External colonization in Bolivia's antinarcotics policy was possible due to the launch of an international regime led by developed countries, which issued multilateral legislation to control the production, commercialization, and consumption of illegal drugs. Based on this legislation, the United States imposed obligations to countries like Bolivia, which had produced raw materials long before drug trafficking began to use these in the production of illegal drugs.

Internal colonization in Bolivia's antinarcotics policy developed in part due to the influence and/or pressure of external power, but was also the result 
of issues inherent in the Bolivian society, including racial discrimination and economic inequality. For centuries indigenous peoples -the first casualties of both Spaniard colonialism, and internal colonialism during the Republic erawere relegated to a subaltern position. This situation that greatly contributed to the exploitation and discrimination of indigenous peoples by the criollo elite, paved the way for internal colonialism in Bolivia's antinarcotics policy. Due to their indigenous roots and impoverished condition, coca farmers were also relegated to a subaltern position in this policy area and become the first casualties in the international fight against cocaine operated in Bolivian territory.

The governing criollo elite adopted multilateral antinarcotics legislation that criminalized the coca leaf and coca chewing, knowingly at the expense of indigenous peoples' cultural beliefs and economic well-being. Likewise, the governing criollo elite enacted US-sponsored antinarcotics policies that criminalized coca farmers and directly affected their security and economic survival through the authorization of forced coca eradication raids, and the establishment of a system of controlled substances that largely punished indigenous poor people.

External colonization and internal colonization reinforced each other. International legislation and US financial, logistical and military support allowed Bolivian governments to violently confront coca farmers (hereinafter cocaleros). By the same token, the passive stance taken by the Bolivian governing elite towards foreign powers allowed the expansion and continuation of external colonization in Bolivia's antinarcotics policy. Before seeing how these interactions developed in the Bolivian case, it is important to describe specific circumstances that have contributed for that to happen: first, the peculiar "intermestic" character of drug trafficking, and second, the main antinarcotics policies issued at the multilateral level and in the United States as part of its foreign drug policy towards Andean countries.

\section{Drug Trafficking: An Intermestic Issue}

Stanford Law Professor Bayless Manning coined the term "intermestic issues" to describe the "simultaneous, profound and inseparably interconnectedness of both international and domestic political issues" (309). Adding to Manning's definition, political scientists Brenner, Haney and Vanderbush pointed out that not only the issues, but also the actors shaping a policy are intermestic: an increasing number of actors are simultaneously 
coping with issues that have both foreign and domestic policy content (Russo and Haney 285-286).

Drug trafficking is an intermestic issue because it does not fit neatly into the classic dichotomy of foreign and domestic policy. It is a transnational phenomenon: a variety of actors across borders participate in the long trade chain that goes from the production of the raw material to the retail sale of illicit drugs in the cities where they are consumed. To control drug trafficking, there is in place an international prohibition regime and the internationalization of law enforcement cooperation. At the same time, as noted by drug policy expert Peter Andreas, drug production, retail sale, and related crimes such as violence and corruption are localized; their control requires policy decisions by national authorities and the creation and/or redesign of state institutions (32).

The intermingled relationship between external and internal colonialism in Bolivia's antinarcotics policy stems from the fact that drug trafficking is an intermestic issue. To face drug trafficking requires both national and international legislation, and especially international cooperation. This situation which has prompted countries to join regional and multilateral efforts to search for solutions has also opened the door for the imposition of policies by powerful countries without considering particular challenges that coca producer countries have to face.

\section{Multilateral Antinarcotics Legislation}

List I of the Single Convention on Narcotic Drugs of 1961 (hereinafter the 1961 Convention) classifies coca as a dangerous narcotic. Article 26 establishes that the parties should enforce the uprooting of all coca bushes which grow wild; and Article 49.e prescribes that the coca chewing must be abolished within twenty-five years from the coming into force of the Convention. According to drug policy analyst Martin Jelsma, establishing that coca producing countries phase out cultivation, production, and consumption of coca, the 1961 Convention provided the international legal basis for the war on drugs approach that developed later (80).

As explained by drug policy experts Bewley-Taylor and Jelsma, the inclusion of the aforementioned clauses in the 1961 Convention was the result of concerns in the developed world about non-medical use of derivatives such as cocaine (6-12). These concerns led to pressure on developing countries to end traditional uses (medicinal, religious, and social traditions) of the plants of 
origin, in order to eliminate the source of raw materials for the production of illegal drugs (Jelsma 78). Without an evidence-based argument that could effectively show that the coca leaf caused a scale of harm, this was included within a system of prohibition and control "in tune with a cultural asymmetry resulting from the dominance of the developed countries of the "North"' (Jelsma 80). Andreas and Duran-Martinez note in this regard that "Nowhere has the asymmetry of power relations been more evident than in the evolution of foreign antidrug policies and the power and influence of the United States in driving the international 'war on drugs'” (9).

\section{US Foreign Drug Policy towards Andean Countries}

Combating drug trafficking has been among US foreign policy priorities, especially since President Richard Nixon declared the Drug War. Moreover, since 1986 when President Ronald Reagan identified drug trafficking as a threat to US national security and demanded a greater emphasis on source control, US administrations have identified drug trafficking as a security issue, and emphasized the supply-side strategy in combating it. This US strategy in Andean countries includes the application of policies that can be classified in mechanisms of control and mechanisms of aid (Hesselroth).

US mechanisms of control include the forced eradication of coca crops, military assistance and the process of certification. For the US government, eradication is the "most cost-effective means of cutting supply" (INCSR ${ }^{1} 2008$ ). Military assistance has funded the creation and functioning of Andean antidrug police units in charge of coca eradication and other interdiction operatives, and the deployment of the US Drug Enforcement Administration (DEA) agents in Andean territory to provide technical support to local antidrug units. Regarding the process of certification, Section 490 of the Foreign Assistance Act of 1961 requires the US president to yearly evaluate the counternarcotics efforts of the major drug-producing and drug-transit countries, to determine if a country may be certified or not. In case of decertification, the sanctions include: the withdrawal of most US foreign assistance not directly related to counternarcotics programs, the suspension of trade-related benefits, and US opposition to requests before multilateral development banks and the

1 INCSR stands for International Narcotics Control Strategy Report, prepared by the Bureau of International Narcotics and Law Enforcement Affairs. Reference under US Department of State 2008 in Works Cited. 
International Monetary Fund. The US president may grant a waiver if it is in the vital national interests of the United States to certify a country.

US mechanisms of aid consist of economic assistance to promote a variety of counternarcotics efforts. Since 1990, these include Alternative Development Programs (ADPs) designed to assist coca producers in the promotion of alternative crops. The Andean Trade Preference Act (ATPA) issued in 1991 and amended in 2002 as the Andean Trade Preference and Drug Eradication Act (ATPDEA), authorized the President of the United States to grant duty-free status or duty reductions to eligible imported goods from Bolivia, Colombia, Ecuador and Peru. ATPDEA expired on July 31, 2013.

\section{Bolivia's Trajectory in the International Drug War}

\subsection{The Coca Leaf}

Since pre-Columbian times, the coca leaf has been part of the daily lives of indigenous peoples. It is a ritual object to invoke the gods for protection, and a symbol of the ethic of reciprocity, which is the moral foundation of traditional Andean culture (Gelles). Indigenous people exchange small bags of coca leaves before discussing important matters, during marriage ceremonies, or to seal long term contracts. Due to its high content of calories and vitamins, and curative effects the coca leaf is also a food staple, an internal medicine, and the basis for coca tea, a remedy for treating symptoms of altitude sickness and fatigue. Coca chewing - practiced individually or in group- is a ritual and a cultural expression of Andean indigenous identity. It produces the elevation of mood or mild euphoria, similar to that produced by a cup of strong coffee, and gives a sense of energy and strength, helping indigenous workers to stand intense physical activity.

For centuries, Andean farmers in the Yungas have grown coca and have sold their coca leaf harvest in legal farmer markets where consumers buy it for traditional uses. However, in the mid-twentieth century, coca began to be identified internationally as the raw material that narcotraffickers utilize to produce the illegal drug cocaine. During the 1970s, cocaine became the popular recreational drug of choice in the United States and Europe, and since then its consumption has largely increased worldwide.

In response to international demand, the supply of coca leaf in Andean countries increased considerably. In Bolivia, this happened in a context of severe economic crisis, unemployment as a consequence of the closing of 
mines and factories, and lack of viable economic opportunities for indigenous peoples living in rural areas. Hundreds of poor families moved to the Chapare valley to grow coca. For the new coca farmers as was the case for the traditional ones, coca became a source of much needed income, and thus, a mean for economic survival. However, pressured by international actors interested in eliminating cocaine consumption through fighting drug trafficking "at the source," the Bolivian government elite issued policies that made of the coca leaf a symbol of criminal activity.

\subsection{Ratification of the 1961 Convention}

The ratification by Bolivia of the 1961 Convention is an episode that determined the complex participation of Bolivia in the international drug war and illustrates the co-existence of external and internal colonization within the area of Bolivia's antinarcotics policy. The classification of the coca leaf as a dangerous narcotic largely contrasts with the cultural perceptions on the coca leaf and related practices held by the Andean indigenous communities in Bolivia. Nevertheless, in 1976 the military dictatorship of Hugo Banzer ratified the 1961 Convention without objecting to that classification. This happened at a time in which the total population of Bolivia was around 4.960 million (US Census Bureau: 1977, 242) and around two million of people -which constituted almost $50 \%$ of the general population and $87 \%$ of the population in small towns and rural communities in Bolivia- used coca leaf for some 40 different remedies (US Congress 1993, 47).

Banzer's stance accepting the criminalization of the coca leaf was both a submissive reaction to the dictates of the international drug control regime, and a blatant omission regarding the defense of the economic, cultural, and social rights of indigenous people -a large sector of Bolivia's population. Furthermore, such a stance in 1976 left a heavy burden for future Bolivian administrations. These inherited not only the obligations resulting from the application of the 1961 Convention which implied the enactment of national legislation to combat coca growing and coca chewing, but also the limitations derived from the criminalization of the coca leaf. Specifically, there is the prohibition (except in very limited circumstances) to promote the legal export of coca and coca-based industrial products. Moreover, the United States has invoked the 1961 Convention to pressure Bolivian administrations to implement forced coca eradication in Bolivian territory. 


\subsection{The Reinforcement of External and Internal Colonization of Antinarcotics Policy}

For International Relations Professor Achin Vanaik, "foreign policymaking as marginalization" occurs when international institutions and major powers - mainly the United States- dictate developing countries' foreign policy decisions and many of their domestic policy choices (Vanaik 55). Because developing nations have to accommodate to the geo-economic and geostrategic interests of the United States, they have constrained choices when designing their own economic and security policies (Vanaik 55-79). During 1982-2004, Bolivia and the United States signed cooperation agreements that emphasized the criminalization of the coca leaf, promoted forced coca eradication raids, and provided US military assistance to support Bolivia's antinarcotic efforts. The content of these agreements and the process through which these were settled -more by US imposition than vis-à-vis bilateral negotiation- reflect the emphasis on mechanisms of control in US foreign drug policy and the interference of the United States in Bolivia's domestic affairs. Moreover, during this period all the Bolivian administrations acquiesced to the application of the policies derived from these agreements despite evidence indicating that these policies affected Bolivia's political stability and the security of its inhabitants, especially in rural areas where coca is grown. Under the threat that Bolivia may be decertified, and/or pressured by the need to obtain economic assistance, the criollo governing elite issued policies that responded to external interests, but also to its own economic and political interests. The resulting situation fits the Vanaik's description of "foreign policy-making as marginalization" and illustrates the interplay of internal and external colonialism in this policy area. Below I refer to some of the most salient events in this regard.

Within the framework of the 1983 US-Bolivia antidrug agreement, President Hernán Siles Suazo (1982-1985) created the Mobil Unit of Rural Patrol (UMOPAR) to oversee coca interdiction operations. Umopar's formation, training, and equipment depended on US funding. Under the threat that Bolivia could lose US economic support for drug control programs and an aid package, Siles Suazo enacted a decree calling for extensive programs of coca eradication and placed the Chapare province under military control (Menzel 10).

In 1986, President Víctor Paz Estenssoro (1985-1989) authorized Operation Blast Furnace, a joint US-Bolivian military incursion in coca growing areas to interdict cocaine laboratories in the jungle and seize the airplanes, 
weapons, and money of drug smugglers. The operation lasted four months, and included six US Blackhawk helicopters and 160 high ranking US Army officers that accompanied Bolivian antidrug police (CIA 1986). Operation Blast Furnace had disappointing results due to press leaks, corruption by Bolivian authorities, and ineffective coordination during the operations (Menzel 21). Furthermore, it ignited public outcry because contravening the Constitution, Paz Estenssoro had allowed without Congressional approval a foreign incursion in Bolivian territory.

Despite intense criticism, Bolivia's drug policy continued under the sway of the US government. "Under 'prodding' from the US, the Paz Estenssoro office drafted a detailed three-year plan to expand interdiction and coca eradication efforts, and signed an antinarcotics agreement with the United States guaranteeing financing, training, and equipment" (CIA 1988, emphasis added). Furthermore, in July 1988, under pressure from the US government, the Bolivian congress passed the Law of Regulations for Coca and Controlled Substances (hereinafter Law 1008), which US legal officials had reportedly helped to draft (Ibid; Ledebur 2005, 145). Law 1008 restricted the cultivation of coca to specific areas to cover legal demand, and declared illegal any coca cultivated elsewhere in the country. It exposed to economic hardship and violence more than a quarter million cocaleros already settled outside of the newly established legal areas, whose livelihood depended on the coca crop (Pop-Eleches 134). Cocaleros in the Chapare had to give up their crops or face brutal eradication operations by Umopar. Either way, they were stripped of their means of economic survival. Clashes between cocaleros and security forces proliferated.

Moreover, Law 1008 imposed excessive penalties for a wide range of activities including manufacturing, distribution and sale of drugs, and established a peculiar judicial process inconsistent with Bolivia's constitutional norms. It presumed the guilt of the accused, ordering prison without the possibility of pre-trial release to those charged with drug offenses -no matter how minor the offense. Even if acquitted, the accused remained in prison until the Supreme Court reviewed the trial court's decision, a process that could last years. A 1995 Human Rights Watch report indicated that the vast majority of defendants under this law were poor people typically charged with involvement in the manufacture or transport of small amounts of drugs.

President Jaime Paz Zamora (1989-1993) initially wanted to improve economic conditions and reduce military intervention in the coca producing areas. However, in his attempt to obtain US economic aid for Bolivia he 
succumbed to US pressure. In May 1990, previous to his official visit to Washington D.C, he declared to the press that due to the considerable reduction of coca growing areas his government had achieved as a result of coordinated efforts with cocaleros, it was not necessary for Bolivia's military to become more directly involved in antinarcotic operations (Isikoff). During his meeting with US officials he urged to place more emphasis on economic aid than on military solutions: "We have 400,000 peasants in Bolivia living from coca and if we eliminate [this trade] they will be unemployed. In your country, it would be the equivalent of 50 million people being unemployed" (Isikoff). However, the Bush administration opted for more emphasis on military solutions and President Paz Zamora acquiesced. He signed the controversial Annex III of the US-Bolivia Antinarcotics Cooperation Agreement which authorized US\$33.2 million of US military assistance and established as a condition for economic aid disbursement the participation of the Bolivian army in antidrug operations. Only after two US-trained Bolivian army battalions participated in a highly criticized operation to locate traffickers and destroy laboratories in October 1991, the United States backed off from drawing the Bolivian army into this project (Human Rights Watch 15).

In the international arena President Paz Zamora unsuccessfully attempted to promote his policy of "coca yes, cocaine no." In 1992, at the UN General Assembly he proposed the amendment of the 1961 Convention, the reversal of the ban on the coca leaf, and more resources to improve ADPs (Paz Zamora 15-17). His long-term plan was to help lift Bolivia out of poverty and end drug trafficking by giving the coca growers the opportunity to export coca tea and other coca-derived products. However, his plans did not go further. US officials opposed Paz Zamora's stance dubbing it as "coca diplomacy" and accused the Bolivian president of using the issue to boost his sagging popularity (Marx). Moreover, the Paz Zamora administration did not initiate the required formal process before the UN for the modification of the 1961 Convention.

President Gonzalo Sánchez de Lozada (1993-1997) had planned the execution of a vast process of privatization of Bolivia's state-owned enterprises. Access to US and multilateral financial assistance were crucial for the realization of this project. In 1995, Bolivia was under the threat of full decertification and the reduction of US economic aid if it did not meet by midyear the coca eradication targets set by the United States. The US President granted a waiver and certified Bolivia, but with an ultimatum including three steps that the Bolivian government should take by June 30, 1995: work on a mutually agreeable extradition treaty with the United States, develop a comprehensive and mutually acceptable plan to eradicate illicit coca 
cultivation, and eradicate 1,750 hectares of coca in the Chapare (Human Rights Watch 17). Under the threat of losing US economic aid and multilateral funding, the Sánchez de Lozada administration reinforced coca eradication. In order to face cocaleros' resistance, the government opted for the escalation of military involvement in counterdrug operations, declared the state of siege for six months, established a curfew, banned meetings, and sparked mass detentions of cocaleros (Ledebur 2002, 12). Moreover, in 1997 Bolivia signed the treaty that legalized the extradition of drug criminals and their prosecution in the United States. Although both countries had signed an extradition treaty in 1900, this did not include drug trafficking among the extraditable charges. The treaty signed in 1997 included drug trafficking.

President Hugo Banzer (1997-2001) established Plan Dignidad (Dignity Plan, hereinafter The Plan), a five-year program to counterattack drug trafficking at many levels and eradicate illegal coca in Bolivia by the year 2002. The Plan ordered the forceful eradication of coca crops, phased out compensated eradication, targeted precursor chemicals, and reinforced the militarization of the Chapare region. The Banzer administration justified the severity of the Plan on the urgent need to remove from Bolivia's international image the stigma of being a corrupted and drug-producing country.

Vice President Jorge Quiroga, the architect of Plan Dignidad, visited Washington D.C. to seek funding for its implementation. He presented the Plan as "the product of a well-conceived political strategy designed to build domestic consensus within Bolivia against the drug trade" (Hastert). Political scientist Muñoz-Pogozian explains that although key sectors had participated in the National Dialogue Plan for 1997-2002 -which included other topics besides drug policy- very few had the opportunity to provide inputs on the technical components of the coca eradication program. Likewise, the Defense Policy Analysis Unit -a think tank within the Bolivian Ministry of Defensewarned in 1999 that the Plan had been written and implemented without consolidating the long-term support of non-governmental organizations (Ledebur 2005, 154). Nevertheless, the US government provided funding for the Plan and stated that Bolivia should "eliminate individually compensated eradication for controlling the cultivation of new coca fields and prosecute those who plant them" (US Presidential Determination No. 98-15). ${ }^{2}$

To implement widespread forced coca eradication operations and prevent the resurgence of coca crops, the Bolivian government increased

\footnotetext{
2 See US Department of State 1998 in Work Cited.
} 
military presence in the Chapare region. The Joint Eradication Task Force consisting of military and police units was created in 1998. Financed by the US Embassy Narcotics Affairs Section, the Eradication Task Force (ETF) was created in 2001. This was a paramilitary counterdrug unit. Although its commanders were military officers, its troops were neither police officers nor soldiers but civilians hired for counterdrug operations (Ledebur 2005, 155). In its short life span (18 months) ETF was implicated in cases of human rights violations in the Chapare, including the death of five coca growers. Credible reports about ETF's violent performance and inquiries by members from the US Congress resulted in the ending of US funding for ETF in 2002 (Ledebur 2005, 156).

Plan Dignidad was very successful in temporarily reducing coca growing areas, but at a high human cost. Illicit coca crops fell from 45,800 hectares in 1997 to 14,600 hectares in 2000. Both the forceful eradication of coca and the elimination of cash compensation, at a time during which ADPs were not adequately provided, left the cocaleros without income and pushed them to extreme conditions of poverty. The initial plan had been to provide ADP to 35,000 families (Ledebur 2002, 5). However, as reported by the US government, only 16,167 families received assistance. Furthermore, updated reports by the Bolivian government in 2001 indicate that only 12,000 families had received ill-funded assistance from all ADP combined (Ledebur 2002, 5). Forced eradication during 1999-2000 outpaced ADP by a wide margin. As of 2001, the US government owed "an outstanding mortgage" to the CounterNarcotics Consolidation of Alternative Development Efforts project in the Chapare. The forceful eradication of coca led to protests that the government confronted with excessive force resulting in alleged human rights violations and deaths: thirty three cocaleros and twenty seven members of security forces died (Ledebur 2002, 12).

When President Banzer resigned due to health reasons, he was succeeded by Vice President Jorge Quiroga. Initially, in order to stop the demonstrations against Plan Dignidad and the related violence occurring in coca-producing areas, Quiroga tried to make some concessions to the cocaleros. Immediately he was severely criticized by the US administration that accused him of being weak in confronting coca farmer leaders (US Department of State INCSR 2002 report). After his visit to Washington DC in 2001, President Quiroga ordered the closing of coca markets in the Chapare and sent military and policy forces to control the area. Violent confrontations between the police forces and the cocaleros resulted in deaths in both sides.

In August 2002, President Gonzalo Sánchez de Lozada began his second presidential tenure. His administration initiated conversations with the 
cocaleros, who in order to obtain the pacification of the Chapare demanded to stop both forced coca eradication and the presence of the military in this area. After a meeting with President Bush in Washington DC in November 2002, Sánchez de Lozada declared that forced eradication would continue. Later the government and the cocaleros held negotiations again but did not arrive upon any agreement. Members of the Bolivian administration were concerned that the plans to solve Bolivia's economic crisis through international financing would be truncated if the pause on coca eradication was approved (Bolivia.com). In 2003, anti-coca eradication demonstrations and a series of protests against the government's economic policies erupted throughout Bolivia, precipitating Sanchez de Lozada's early resignation.

In sum, during the governments led by the criollo elite, Bolivia signed bilateral agreements with the United States assuming obligations in the socalled War on Drugs. In exchange, Bolivia obtained economic and military assistance to fulfill these obligations and to pursue other endeavors mainly in economic policy. The governing elite's rhetoric assured that the accomplishments in both the war on drugs and economic reform would help Bolivia to clear its international reputation, improve its economy, and be in its way towards modernization. However, the application of policies in tune with external pressure mainly benefitted the upper classes and foreign investment. To make things worse, the formulation of antinarcotics policies did not consider the basic needs, rights, and cultural values of indigenous peoples that consume the coca leaf and/or were involved in its production and commercialization. As noted by Fernando Salazar, during 1980-2004 the violence related to forced coca eradication in the Cochabamba Tropic resulted in the deaths of 95 civilians and 23 police and military forces, and 5,349 cases of human rights violations.

\section{The Process of Decolonization during the Morales} Administration

\section{Latin American Perspectives on Decolonization}

Since the 1990s Latin American intellectuals have produced literature on how to overcome the negative influence of Western knowledge. For Anibal Quijano, Eurocentrism operates "as a mirror that shows a partial and distorted 
image of what is reflected," hampering the accurate analysis of political processes and thus, the emergence of revolutionary projects that could bring solutions suitable to Latin America (550-556). To confront this coloniality of power, he suggests getting free from that mirror, otherwise, "we will continue being what we are not [...] and can never identify our true problems, much less resolve them, except in a partial and distorted way." (556). Enrique Dussel proposes a trans-modern project of liberation that begins with cultural resistance: the self-valorization, cultivation, and development of one's own cultural traditions; then, it proceeds to an intercultural dialogue which is neither modern nor post-modern, but trans-modern because the creative force comes from the exteriority of Modernity (50). Walter Mignolo emphasizes the logic of colonial difference: because of the particular experience of local history, knowledge production from the subaltern position of the peoples of the South provides a more substantive and thus liberating critique of modernity (37-39).

Regarding perspectives on decolonization in Bolivia, Rivera Cusicanqui notes that long before the coloniality of power studies, indigenous intellectuals based on their own struggle experience drew specific proposals for contemporary decolonization (2010, 54-69). Indeed, Aymaran historian Waskar Ari indicates that from 1920 to 1960 the leaders of Alcaldes Mayores Particulares, a 450-cell network of indigenous intellectuals and activists questioned republican law and proposed subaltern nationalism, envisioning a separate republic of Indians governed by Indian Law and rooted in both Andean pre-Hispanic religion and tradition. During the 1960s and early 1970s Fausto Reinaga developed a proposal for emancipation that according to Bolivian sociologist Esteban Ticona "is a libertarian episteme that undoubtedly contributed to the construction of a decolonizing knowledge." Embracing the term Indio as an ethnic, cultural, and political identity linked to a liberalizing role, Reinaga proposed an Indian Revolution, for the destruction of colonialism that did not imply going back to the Tawantinsuyo, but to build an Indian nation taking into consideration the present circumstances (Ticona). For Rivera Cusicanqui, who points out that decolonization should be not only a discourse but a substantive reflection that relies on the struggling subaltern's own experience, decolonization is about shifting the epistemological center, allowing new forms of knowledge to evolve and be recognized, a sort of decolonization of the mind in which the rediscovery and use of indigenous cultural values, for instance native languages, is very important (Rivera Cusicanqui 2010, 73. Author's translation). 


\section{Incipient Efforts of Decolonization on the threshold of the New Century}

In the 1990s and 2000s, in an attempt to call the attention of the central government to their demands, indigenous communities throughout the Bolivian territory organized long and multitudinous marches -marchas indigenas - to the city of La Paz. For instance, in July 1990, indigenous Amazonian Peoples and Andean communities convoked the First March for Territory and Dignity. In 1996, the March for Territory, Land, Political Participation and Development was organized by the Confederation of Indigenous Peoples of Bolivia (Confederación de Pueblos Indígenas de Bolivia, CIDOB), the Confederation of Rural Workers of Bolivia (Confederación Sindical Única de Trabajadores Campesinos de Bolivia, CSUTCB) and the Bolivian Syndicalist Confederation of Colonizers (Confederación Sindical de Colonizadores de Bolivia, CSCB). In 2000, the Regional Federation for Santa Cruz (Coordinadora de Pueblos Étnicos de Santa Cruz, CPESC) and several Amazonian peoples' organizations participated in the March for the Earth, Territory, and Natural Resources. In 2002, the lowland indigenous peoples of the Oriental block of $\mathrm{CIDOB}$ and the highland indigenous communities represented in the National Council of Ayllus and Markas of Qullasuyu (Consejo Nacional de Ayllus y Markas del Qullasuyu, CONAMAQ) launched the March for Popular Sovereignty, Territory, and National Resources.

Although the incumbent governments did not respond to all the demands coming from the marchas indígenas, as a result of these mobilizations important legislation was approved including the modification of the Law of Agrarian Reform, and the official recognition of lowland indigenous languages and three indigenous territories. In the marcha of 2002 the demand for a new constitution to re-found the state emerged among grassroots organizations. To this end, these organizations joined efforts and sealed the Pacto de Unidad (Unity Pact) in 2004. The support that the unity pact granted to Morales was crucial for his election as president in 2005.

Bolivia also witnessed the Guerra del agua in 2000, and the Guerra del gas (Gas war) in 2003, social mobilizations in which multi-class and multisectoral cooperation were salient. Indigenous communities, traditional and new peasant trade unions (including the cocaleros), neighborhood associations, university student organizations, and common citizens -from the middle and lower classes and from rural and urban areas- mobilized against the privatization of the local water company in Cochabamba, and later against 
the Sánchez de Lozada government's proposal to export natural gas through Chile to the United States. Both mobilizations were successful in truncating the projects of privatization they had opposed, and in building ample support for the writing of a new constitution that would dismantle neoliberalism.

In sum, prior to the installation of the Morales government the efforts of decolonization included both demands against internal colonialism, for the recognition of indigenous cultural values, autonomy, and territory; and demands against the neoliberal economic order, specifically against the dependence on foreign investment and foreign institutions. As described in the following sections, the Morales government has implemented these two main demands in both its general program of decolonization and the one pursued specifically in the antinarcotics policy area.

\section{The Plurinational State of Bolivia's Contemporary Process of Decolonization}

Formally, considering the Plan Nacional de Desarrollo, (National Development Plan) and Articles 9.1 and 78.1 of the Constitution, decolonization may be described as the dismantling of the neoliberal and colonial state through policies for the elimination of discrimination and exploitation, the implementation of social justice, and the strengthening of plurinational identities. In practice however, the government has focused on the revalorization of indigenous values, traditions, and knowledge, and the application of policies to strengthen the state and cut dependence from foreign powers. The project of plurinationalism understood as the autonomy of the indigenous communities in the management of their territory has received less attention, which has caused resentment in indigenous communities, leaders, and intellectuals.

Regarding the revalorization of indigenous culture, it is particularly interesting that besides his formal first presidential inauguration in La Paz, Morales celebrated his ritual inauguration in Tiwanaku, the country's premier archaeological site. Dressed in indigenous attire he claimed that the beginning of his government marked the death of a colonial state that had always seen indigenous peoples as savages (Página 12. Author's translation). As noted by scholar Andrew Canessa, this event was an explicit affirmation of the Morales government's decision to place indigeneity at the very center of the way in which it presents itself to its citizens (154). Indeed, indigeneity is also at the 
center of its program of decolonization. Several times President Morales has returned to Tiwanaku to renew his mandate and to celebrate the Aymara New Year on June 21st. Often he and members of his administration claim that the way to put decolonization in practice is through celebrations that recover "the identity" of the indigenous communities (Radio Cepra). Moreover, in 2009 the Morales government created the Vice Ministry of Decolonization (VMD) as part of the Ministry of Cultures, with a mandate to develop policies for the revalorization of the ancestral knowledge and values of the indigenous peoples, and for the prevention and eradication of discrimination, racism, xenophobia, and cultural intolerance (Decreto Supremo 29894, Art. 116).

Regarding the independence from foreign powers, President Evo Morales and members of his administration maintain that the nationalization of the hydrocarbons industry, which Vice President Garcia describes as "economic decolonization," is one of the crucial moments of Bolivia's decolonization ( $\mathrm{La}$ Razón). Today the Plurinational State of Bolivia owns the hydrocarbon industry. In contrast to previous administrations, the Morales government is taxing foreign investment considerably. During 2005-2014 revenues from the hydrocarbon sector have increased almost seven fold in nominal US dollars (Lefebvre \& Bonifaz).

However, within Bolivian society there are different versions of what decolonization means in practice. For instance, among grassroots organizations there is not an agreed-upon definition. Anthropologist Almut Schilling-Vacaflor explains that for CONAMAQ and CIDOB -whose members are indigenous and original peoples- decolonization means to recover and reconstitute precolonial structures and to achieve greater self-determination and autonomy, which implies direct representation in the legislative power and the recognition of their autonomous territories. In contrast, for CSUTCB -a heterogeneous organization that represents indigenous originario and campesino communities with highly active syndical experience, and closely aligned with MAS and the Morales government- the goal of decolonization is the transformation of the state to recover Bolivia's economic sovereignty (Schilling-Vacaflor).

For Silvia Rivera Cusicanqui, decolonization should be about advancing the autonomy of indigenous communities (Erbol digital). Likewise, for Bolivian political analyst Raúl Prada "the only viable path towards decolonization is the construction of a plurinational State" (as cited in Aguilar, author's translation). Therefore, both thinkers criticize the government's own version of decolonization that focuses on the display of indigenous rituals and symbols. 
For Rivera Cusicanqui, the government is mounting a "decolonization show without a meaningful social impact," and the program of decolonization is not moving forward because the government has reduced decolonization to the functions that the VMD has in the Ministry of Cultures. For Prada, the government's program is a "tinsel decolonization": a folklorization of the ceremonial power that is still colonial because it has not pursued plurinationalism. Highlighting a related problem, anthropologist Luz Jiménez notes that instead of recognizing cultural diversity encompassing both Andean and Amazonian indigenous peoples, the government's policies are based on Andean nationalism (183).

Many activists and scholars also criticize that the Morales administration like previous governments continues to promote extractivism and intensive agriculture and consequently, the Bolivian economy is still largely dependent on transnationals and the export of raw materials. Additionally, critics point out that the redistribution of profits from the extractive model through financing development, infrastructure, and especially social welfare programs, benefits the state which gains widespread support at the expense of the indigenous peoples' well-being. Indeed, most of the gas and oil concessions granted to transnationals or large infrastructure projects are located in lands that belong to indigenous communities which have to carry the burden of environmental damage. The affected communities have protested, but the government is rejecting their demands under the argument that the natural resources belong to all Bolivians and that development projects benefit all Bolivians. Scholar Nancy Postero describes the Morales government's stance as an example of continued colonialism by a profoundly liberal centralized state that unilaterally decides what is good for the people (419).

The cocaleros are affiliated to CSUTCB which shares the Morales government's nationalist vision of decolonization in which indigenous values and culture provide the moral foundation for the strengthening of the state as a whole (Schilling-Vacaflor). Therefore, for them the government's emphasis in displaying and imposing Andean or newly invented indigenous rituals and symbols is not a problem, but an opportunity. The coca leaf is almost always present in the typical celebrations promoted by the government. It is not an accident that, during his ritual inauguration in Tiwanaku, Morales walked barefoot over paths covered with coca leaves to the top of the Akapana pyramid. Moreover, the Morales administration's rhetoric insisting on the revalorization of indigenous ancestral values is a crucial statement in the argument that the government uses for the defense of the coca leaf and coca chewing in international fora. 
The cocaleros from the Chapare do not have an ancestral history of settlement (Canessa 160). As migrants from different regions, they originate in traditional indigenous communities and have an historical consciousness of racism and injustice, but they do not identify closely with the lifeways and cultural values of their communities of origin (Canessa 161). Therefore, territorial autonomy is not necessarily in the cocaleros' agenda. Instead, they are guided by economic survival. They operate where coca grows. CSUTCB supports the nationalization and industrialization of Bolivia's natural resources (Schilling-Vacaflor). The cocaleros also support these strategies because they have benefited (especially in the Chapare) from the infrastructure built by the government's redistribution of revenues from hydrocarbons. Local municipalities have engaged in a range of projects to improve transportation infrastructure, health care and education services, and agricultural and cattle production (Ledebur and Youngers).

In sum, many social actors, especially those that advocate for indigenous communities' autonomy and their right to decide about the natural resources located in their lands, are contesting the government's program of decolonization. Since their interests and concerns vary from those of other indigenous communities, the cocaleros support the Morales government's own version of decolonization. Even those from the Yungas who differ with Morales in some terms of coca policy, are " $100 \%$ behind his plans to change Bolivia" (as cited by Durand 178).

\title{
The Plurinational State of Bolivia's Antinarcotics Policy
}

\author{
1. Internal Decolonization of Antinarcotics Policy: "coca yes, \\ cocaine no."
}

In 2004, based upon the cocaleros' proposal that previous governments had rejected, President Carlos Mesa signed the Chapare agreement which established 3,200 hectares as the limit for legally grown coca in the Cochabamba Tropic. Each family registered in the coca federation was allowed to produce one cato (1,600 square meters) of coca. This system permitted the cocaleros to have access to their subsistence plot of coca leaf without 
confrontations with the police. In 2006, recently inaugurated President Evo Morales announced that his government would pursue "the fight against narcotraffic and not against the cocalero, as previous administrations had done" (Bolpress). His administration extended the original one-year term of the Chapare agreement and established the policy "coca yes, cocaine no" based on these pillars: 1) recognize the positive attributes of the coca leaf; 2) industrialize coca for licit uses; 3 ) continue rationalization of coca (voluntary eradication) in the Chapare and extend it to other regions; 4) increase interdiction of cocaine at all stages of production (Ribando 12).

In order to extend the coca rationalization program beyond the Chapare, the government launched a plan that eliminated the division of Bolivian territory into legal, transition, and illegal zones established by Law 1008, allowing each cocalero union member in any preexisting coca growing region to grow one cato of coca. The government also began negotiations with the Yungas agrarian federations to determine the number of cato plots assigned to their members and the gradual and systematic cooperative eradication of excess coca cultivation. An agreement with the Yungas of La Paz was reached in 2008. More negotiations -some of them difficult- have followed to determine new arrangements in the Yungas and surrounding areas (Mendoza).

In 2009, an innovative social control program -which drug policy experts Linda Farthing and Kathryn Ledebur accurately describe as "community coca control" - was launched to improve the system in place since 2005. It adds sophisticated technological monitoring, land titling, and economic development, but continues largely relying on the high levels of organization of the cocaleros' federations. The unions are in charge of enforcing the agreements, organizing and operating the control process, and coordinating the peaceful eradication of coca grown in excess of the cato limit (Ledebur and Youngers 3). They inspect the coca fields and inform about irregular cases so the special police forces could come to the area and proceed to do the eradication. Likewise, the federations are entitled to impose sanctions: repeating offenders risk losing their right to grow any coca and even their land. Contravening of the cato limit is seriously rejected by the union and the community. The community control system is based on "deeply entrenched cultural values that emphasize the importance of community participation through peasant unions" (Farthing and Ledebur 10). By encouraging the coca growers to exercise informal and internal controls through the unions, the control program prioritizes collective over individual rights (24).

The new policy of negotiation and cooperative coca reduction counteracts the violence and negative economic impact on cocaleros caused by the US- 
sponsored forced coca eradication. There have been some violent incidents in certain traditional coca growing areas and national parks where the government has pledged to eliminate all coca and the cocaleros have resisted eradication. However, these incidents are the exception and not the rule as it used to be during the violent coca eradication raids ordered by previous governments (Ledebur and Youngers 3).

According to the 2011 and 2014 UN Office on Drugs and Crime (UNODC) reports, the Bolivian government's efforts in rationalization/eradication has achieved among other feats a significant reduction of coca crops (UNODOC 2012 , 6). During 2010-2014 there was a decrease of 34\%, representing a reduction of more than one third compared to the surface cultivated in 2010, bringing the number of hectares of coca crops in the year 2014 to the lowest figure recorded by UNODC since the monitoring of coca began in Bolivia in 2003 (UNODC 2).

In order to promote the recognition of the positive attributes of the coca leaf and provide cocaleros with legally viable economic opportunities, the Morales government is investing in projects for the industrialization of cocabased products. These projects have the potential to benefit coca growers in both traditional and newly colonized zones, as well as others who will become involved in the factory work, distribution, and marketing, on the national and eventually international markets (Conzelman). During the first term of President Morales his administration restored two factories in the Yungas region and worked in the installation of a new one in the Chapare. The factories in the Yungas had been built in the 1980s with UN funding, but they fell into disuse during the escalation of the US War on Drugs that prioritized the substitution of coca crops (Conzelman). Currently the Yungas factories produce bagged coca tea and coca flour. Because currently the exports of coca-based products are prohibited by the 1961 Convention, these factories' production is sold only in the domestic market. This is a huge obstacle for the expansion of production. In 2012 the Morales administration announced the beginning of three industrial projects for the production of coca tea, cereals and medicines (Mealla 2012b).

Moreover, the Bolivian Constitution approved in 2009 explicitly recognizes that in its natural state coca is not a narcotic. According to Article 384 the State protects the native and ancestral coca as cultural patrimony, as a renewable natural resource of Bolivian biodiversity, and as a factor of social unity. An important constitutional mandate in this regard is Article 255 which establishes that the negotiation, signing, and ratification of international 
treaties should be done "rejecting all forms of colonialism, neocolonialism and imperialism, defending and promoting human rights, economic, social and cultural rights, repudiating racism and discrimination, and respecting the rights of native indigenous rural peoples."

In sum, the "coca yes cocaine no" policy includes the two main features of the Morales' program of decolonization: the revalorization of indigenous values and practices through the recognition of the attributes of the coca leaf and the implementation of the community control program; and the independence from external actors through the prohibition of the US sponsored policy of coca eradication, and Article 255 of the Constitution. Precisely, as described in the next section, based in this constitutional mandate the Morales administration has taken important steps towards external decolonization in the antinarcotics policy area.

\section{External Decolonization of Antinarcotics Policy}

President Morales began an international crusade to inform the world about Bolivia's policy of "coca yes and cocaine no" and to obtain international acceptance for the use of the coca leaf in Bolivia for medicinal, ritual, and cultural purposes. In March 2006, before the UN Commission on Narcotic Drugs session in Vienna, the Bolivian delegation underlined that from the standpoint of respect for ancestral cultures and the indigenous population's identification with the coca leaf as a sacred cosmological element, there was a need to reexamine the value and importance of the coca leaf (Vice Minister of Coca Felix Barra, as cited in Metaal 2006, 4).

In 2007, the UN International Narcotics Control Board (INCB) called on countries to abolish or prohibit coca leaf chewing and the manufacturing of coca-tea. President Morales responded that Bolivia did not accept unilateral certifications or impositions from foreign governments (see letter by Evo Morales, reproduced by Transnational Institute). Making reference to developments in International Law on the rights of indigenous peoples, Bolivia rejected illegal drugs trafficking, but it also reaffirmed its right to preserve cultural values such as the consumption of the coca leaf. Among the international legislation mentioned in this letter was the UN Declaration on the Rights of Indigenous Peoples approved in 2007 which states in article 11: "Indigenous people have the right to practice and revitalize their traditions and cultural customs." 
Regarding bilateral relations, in 2008 President Morales suspended the operations of the DEA, the major US agency dedicated to eradication of coca crops. As of January 2009 all the agents had left, putting an end to more than three decades of the DEA's presence in Bolivia (Kraul). In August 2011, the US Agency for International Development (USAID) was expelled from Bolivia's largest coca-growing region. The government has taken full responsibility for all drug-control missions in Bolivia. In spite of these events, bilateral negotiations to fight against narcotraffic continued and on January 2012, Bolivia signed with Brazil and the United States a technical cooperation agreement on the Integrated Monitoring System for Surplus Coca Cultivation Reduction. Previous administrations had signed antinarcotics agreements that amply allowed the United States to perform a series of activities within Bolivian territory. In contrast, this trilateral agreement establishes that while the United States and Brazil will provide technical assistance, training, and satellite images of areas where coca is grown for the illicit market, only Bolivia will conduct the fieldwork. Precisely, in order to avoid any confusion on the participation of Brazil and the United States, the Morales administration delayed five times the signing of this agreement, requesting more specific wording regarding Bolivia's core role in the reduction of surplus coca cultivation (Calizaya). Minister of Government Wilfredo Chávez commented that, although to combat a transnational crime like drug-trafficking a cooperative work is necessary, "this fight will be done respecting the sovereignty of the Bolivian state" (Calizaya).

After the approval of the new Bolivian Constitution in 2009, President Morales doubled his efforts to defend the coca leaf in the international arena. Article 255 of the Constitution placed a deadline of four years to renegotiate or withdraw from international treaties that were in conflict with the new Constitution. In order to eliminate the obligation established in the 1961 Convention that "coca leaf chewing must be abolished" President Morales formally requested that Article 49, paragraph 1 (c), and paragraph 2 (e) of the Convention be deleted. The United States publicly opposed the amendment and in coordination with the INCB convened a group so-called "friends of the convention" to rally against Bolivia's request (Jelsma). Eighteen countries registered objections. Bolivia's proposal was defeated. This failure, however, did not stop the Morales administration's efforts. Instead, it ignited an unprecedented diplomatic move.

In June 2011, Bolivia denounced the 1961 Convention for its failure to recognize coca chewing. It was the first country ever to withdraw from this Convention. President Morales said his country would rejoin if Bolivia was 
allowed to continue the traditional consumption of coca leaf. Four months later, Bolivia applied for re-accession to the 1961 Convention, with a reservation noting that it did not recognize the ban on the growing and chewing of the coca leaf. The Morales administration lobbied international forums and foreign governments to obtain their support for its re-admission. In March 2012, President Morales visited the UN Commission on Narcotic Drugs to explain the importance of the coca leaf in Andean culture, and its pharmaceutical and industrial use. The same year, responding to Bolivia's request, the Non-Aligned countries' summit held in Iran and the IberianAmerican Summit held in Spain issued communiqués recognizing coca chewing in Bolivia.

The United States reacted against Bolivia's request arguing that a reservation would lead to a greater supply of available coca, and thus, to more cocaine for the global cocaine market (UN Depositary notification). Likewise, the head of UNODC warned that in the long run Bolivia's reservation could have a domino effect and undermine international law in the area of drug control (Dahl). Despite these criticisms, the Morales administration's diplomatic efforts paid off. The majority of the parties of the 1961 Convention did not object to Bolivia's readmission or to the new statute which says that chewing, and growing the coca leaf, is fine within Bolivia. In 2013 Bolivia re-joined the Convention. Since then President Morales has embarked upon another challenging project: lobbying the international community to obtain support for the authorization to export coca leaf and coca based products which currently is prohibited except in exceptional cases that are strictly regulated and limited.

\section{The Cocaleros and the Decolonization of Antinarcotics Policy}

The cocalero movement is not monolithic. The cocaleros from the Yungas and those from the Chapare region (Morales' strong basis of support) are different in many aspects. The former, especially those from the Yungas La Paz are predominantly Aymaras, have settled there for centuries, do not use fertilizers to grow coca, pick the coca leaves one at a time, and have ceremonies after the harvest (as cited by Durand 178). The majority of Chapare cocaleros are colonizers: Aymara and Quechua peasants from the highlands that arrived to the area during the 1950s and 1960s searching for land and 
economic opportunities. Those that arrived during the 1970s and 1980 s came from closed factories and mines, driven by Bolivia's economic crisis.

In 1985 Law 1008 declared the Yungas La Paz and Yungas Vandiola as traditional areas where coca growing was permitted. Therefore, the Yungas cocaleros have not been exposed to the constant military intervention and forced coca eradication that for decades affected the Chapare cocaleros' security and mean of economic survival. This is a considerable difference that influences the reaction of these two groups to the "community control" policy based on the cato limit (Farthing and Ledebur). In order to avoid the horrible experience that coca eradication brought for their lives and communities, the Chapare cocaleros are ready to accept other solutions such as the cato system, even if this implies a limit in the quantity of coca they can grow. The Yungas cocaleros are more reticent to limit or reduce their production, because this implies a huge change to the status and income they have held as traditional cocaleros (Farthing and Ledebur 24).

Another difference is that the Chapare cocaleros are very well organized in their Six Federations of Coca Unions of the Tropics of Cochabamba. Scholar Francisco Thoumi explains that those that migrated from places where union activity was strong brought with them their union loyalty and organization mode (Thoumi 112-113). Furthermore, they have a special relationship with President Evo Morales who since 1996 is the Executive Secretary of the Six Federations, and is also the leader of MAS, the political party to which the cocaleros are affiliated. The Yungas cocaleros are not a unified force. Anthropologist Caroline Conzelman explains that the traditional cocaleros socalled "protectionists" reject limitations and want to defend their localized niche economy; while the more recently installed cocaleros so-called "nationalists" that have colonized areas in and around the legal zones have agreed to the cato and have negotiated with the government cooperative coca reduction agreements. These tensions make it very difficult for the Yungas cocaleros to present a united front (Farthing and Ledebur 24).

Nevertheless, there are important similarities among the Yungas factions and the Chapare cocaleros. Added to the profound respect they have for the coca leaf which they consider sacred, there is the need to count on the income coming from the cato (Farthing 2014). All the cocaleros are involved in market activity. Even the Yungas La Paz cocaleros have changed their peasant attitude towards land management and increased their interest in short term profit in their decision making process (Thoumi 111). From both a cultural and a commercial point of view all the cocaleros benefit from a government that 
promotes the ancestral and practical values of the coca leaf, and is able to contest international legislation in order to fight the criminalization of the coca leaf and the coca chewing, and to negotiate the possibility of opening legal export markets for coca and coca based industrial products. Thus, despite some problems that might exist regarding the implementation of the cato system, the coca leaf becomes a unifying source. Farthing, who has made extensive field research in the coca growing areas mentions that leaders from the Yungas assure that they want to cooperate with the community control system because they have consciously understood the importance of limiting coca growing and do not want Bolivia to have a bad international reputation. "There is a sense of pride on being international participants in the fight against narcotraffic" (Farthing 2014).

\section{Hybrid Strategy of Decolonization in the Promotion of the Coca Leaf}

Linguist scholar Rosaleen Howard observes that right-wing discourse in Bolivia portrays decolonization under the MAS-Morales government as opposed to superior Western modernity and, thus, as the reproduction of "backwardness" (187). However, the program of decolonization includes initiatives especially in the economic arena that are far from the "backwardness" or rejection of Western modernity suggested by right-wing discourse.

While in order to embrace Andean indigenous traditions and identity the Morales administration looks at the past, it also takes into account present and future opportunities that may help to ensure the cocaleros' well-being. For instance, according to Decreto Supremo 29894, the Vice Ministry of Coca and Development must "propose, coordinate, and implement policies for industrialization, trade, medicinal and cultural use, and export of the coca leaf, respecting multicultural values" (Article 113); and the Vice Ministry of Rural Development and Lands must promote the traditional uses of the coca leaf, encourage scientific research on the coca leaf, and support industrial and commercial activities that may contribute to the economic development of the coca producer zones (Article 109). Moreover, the National Development Plan and the Constitution establish that the Plurinational State of Bolivia should adequately participate in international economic relations, work on the export of value added goods, and facilitate the role of innovation and technological 
development in the increase of productivity and competitiveness. The Morales government is following these guidelines in its general program of decolonization and in its antinarcotics policy. The result is a hybrid strategy that includes both the promotion of Andean values, traditions, and knowledge, but also the participation in international economic relations and in technological and economic opportunities the market may offer.

Far from rejecting Western legislation and institutions, the Morales administration is utilizing International Law as well as legal tools and channels provided by the international antinarcotics regime. For instance, it has followed the corresponding procedures established by the Law of International Treaties and by the 1961 Convention in order to obtain in the international arena the depenalization of the ancestral practice of coca chewing. Moreover, the Morales government has not retracted from the antinarcotics commitments that Bolivia had previously assumed in the international antinarcotics regime. On the contrary, Bolivia is actively participating in the fight against narcotraffic. It has signed bilateral and multilateral agreements of cooperation, joining new efforts with countries and international organizations to stop the illegal production of coca, the traffic of cocaine and precursor chemicals, and other narcotraffic-related illegal activities.

\section{An Incomplete Process of Decolonization}

Since its approval in 1998, Law 1008 has been criticized by national and foreign political analysts and drug policy specialists because it was designed by US officials and its enactment was the result of pressure from the United States. Furthermore, its provisions are unconstitutional and draconian; and its application greatly facilitates the violation of human rights. Moreover, Law 1008 covers two different aspects: on the one hand, it contains dispositions of socioeconomic order related to the cultivation of the coca leaf; on the other hand, it contains norms on criminal law matters related to the judicial process and the application of penalties for drug trafficking (Metaal 2010). A shared opinion among analysts is that both aspects should have never been regulated under the same law.

The Law of Judicial Bond approved in 1996 and the Criminal Procedure Code approved in 1999 modified some of the procedural regulations of Law 1008. The benefit of conditional release was established for cases involving delays of justice, along with more guarantees for the exercise of the right to defense by the accused. Yet, as noted by drug policy analyst Diego Giacoman, 
the application of excessively harsh penalties has continued, and because the requirements for conditional release are not viable for most of the accused, the new regulations have not helped to reduce significantly the number of people incarcerated for drug-trafficking and related offenses. As of 2010, Law 1008 accounted for $45 \%$ of the total prison population nationwide; more than $67 \%$ of those incarcerated were being held in pre-trial detention (Giacoman 23 24).

Research by Human Rights Watch indicates that most of those in prison due to Law 1008 are not the big drug traffickers, but minor offenders who in their vast majority are poor people and whose participation in the drug trade is usually as pisacocas (coca stompers), mulas (mules or couriers) and hormigas (ants: those that transport very small quantities) (Human Rights Watch 24). Even though these people are the weakest, poorest, most vulnerable, and easiest to replace in the drug-trafficking chain, they are serving disproportionately long sentences (Giacoman 23).

The case of poor women incarcerated for drug trafficking is particularly dramatic. In her study of Bolivian prisons, drug policy specialist Rose Marie Achá indicates that as of the end of the 1990s, $60 \%$ of the women imprisoned were held for violations of Law 1008. Most of them were between 20 and 35 years of age, single heads of households, and had received little or no formal education. In the Cochabamba's San Sebastian women's prison $90 \%$ of the prisoners were there for drug trafficking, most were internal migrants, $70 \%$ had come from rural areas, many knew little or no Spanish, and those who spoke Spanish had a vague or no understanding of the criminal justice system and its procedures (Achá, cited by Diaz-Cotto 191).

The 2013 report by the Inter-American Commission on Human Rights (IACHR) highlighted that from a total of 13,654 people deprived of liberty in Bolivia, 1724 were women -which represented $1 \%$ of the prison population, the highest percentage of women incarcerated in South America- and $48 \%$ were incarcerated primarily for drug related crimes (see reference under $\mathrm{OEA} / \mathrm{CIDH}$ ). Furthermore, many of these women are mothers who bring their children to live in prison with them because in the absence of a social policy for minors in Bolivia, their children have no safer place to be than in the prison (Giacoman 23).

For years, scholars, human rights activists, and politicians have demanded the modification of Law 1008. Prior to 2005, the main barrier was the objection by US officials, even though they also acknowledged that the procedural aspects of Law 1008 affected human rights (Farthing 1997, 255). They feared 
that any reform of the law would go beyond remedying its procedural defects and would extend to the substantive provisions that supply the legal structure for counternarcotics operations (Human Rights Watch 26). The other obstacle was the indifference of the governing criollo elite regarding the punishment system created by Law 1008. When the bill of Law 1008 was debated in Congress, this debate centered on the regulation of coca rather than the law's provisions on controlled substance offenses; there was "relatively little public debate about the special procedures and institutions created for the prosecution of drug cases" (Human Rights Watch 21). Such a passive stance continued during the next decade despite mounting evidence on the struggles that poor people, especially poor women, were facing as a consequence of the excessive penalization and unconstitutional procedures established in Law 1008.

In 2006 the Morales government promised to modify Law 1008, but after a decade in power it has not issued a substantive modification. The problem is that the debates in the Plurinational Assembly about a possible modification are focused on the regulation of coca, leaving aside of the discussions the law's provisions on controlled substances offenses. In the current political scenario, the regulation of the coca leaf has become an even more sensitive issue. Due to the links between MAS the governing party and the cocalero movement, the opposition sees with suspicion any proposal from MAS to discuss the modification of Law 1008: "The governing party owes political favors to the cocalero unions. No bill that comes from the governing party responds to the interests of our country" (Bejarano. Author's translation). Even in rare occasions when there is a discussion about the regime of controlled substances established by Law 1008, the confrontational stance has continued. For instance, despite evidence supplied by specialized research regarding the need to reduce the excessive penalization for minor trafficking, political parties of the opposition have proposed to include harsher penalties: to increase from two to fifteen the number of years of incarceration for the pisacocas (see reference under Eju!).

In sum, Law 1008 is a symbol of external and internal colonialism in Bolivia's antinarcotics policy. It was enacted due to pressure from the United States, and as explained above, its regulations on the coca leaf did not contemplate the security, economic well-being, and cultural traditions of coca farmers and its normative on the system of controlled substances is inconsistent with constitutional precepts. As observed by Washington Office for Latin America (WOLA) and Transnational Institute (TNI), the system of 
punishment created by Law 1008 reaffirms an iron fist approach that does not address the issues of poverty and lack of opportunities that push people living in socio-economic disadvantaged situations into micro-drug trafficking. The related problems derived from its application such as the overcrowding in prisons and the strenuous conditions that incarcerated women with children have to face, accentuate the negative impact of that iron fist approach. The long-postponed modification of Law 1008 is a considerable flaw not only regarding the Morales government's management of Bolivia's antinarcotics policy but also with respect to its larger project of decolonization that according to the Constitution is supposed to promote "policies for the elimination of discrimination and exploitation, and the implementation of social justice."

\section{Concluding remarks}

Because of the interplay of internal and external colonialism in Bolivia's antinarcotics policy, the decolonization in this policy area requires a twofold effort. Through the issuing of reforms applicable in Bolivian territory and the use of venues offered by international law, the Morales administration has defied decades of blatant submission of the Bolivian governing elite to external power. It has also curtailed the discrimination and violent confrontation enforced by previous administrations against cocaleros. From being a policy taker of US-designed strategies, Bolivia has become its own antinarcotics policy maker. Likewise, from being a passive actor in the international arena, Bolivia has become an active player. An important achievement in this regard is the recognition by the international antinarcotics regime of the traditional uses of coca leaf in Bolivian territory. Nevertheless, the decolonization of Bolivia's antinarcotics policy is still a work in progress. At the international level, the difficult task of obtaining the authorization to export coca and coca industrial products is in its incipient stage. At the national level, the modification of Law 1008 is pending. This modification however is imperative. 


\section{Works Cited}

ACHÁ, Rose Marie. 2011. “Una nueva Ley de Drogas en Bolivia.” La Razón (La Paz) 23 de diciembre 2011. [http://www.larazon.com/index.php?_url=/suplementos/la_gaceta_juridica/nueva-LeyDrogas-Bolivia_0_1528047230.html] downloaded November 27, 2015.

AGUILAR AGRAMONT, Ricardo. 2012. "La descolonización aún se encuentra en el plano discursivo." La Razón (La Paz) 26 de agosto 2012 [http://www.larazon.com/suplementos/animal_politico/descolonizacion-encuentra-planodiscursivo_0_1675632467.html] downloaded November 20, 2015.

ANDREAS, Peter and Angelica Duran-Martinez. 2013. The International Politics of Drugs and Illicit Trade in the Americas. Watson Institute for International Studies Research Paper 2013-05. [http://ssrn.com/abstract=2326720] downloaded March 10, 2015.

ARI, Waskar. 2014. Earth Politics. Religion, Decolonization, and Bolivia's Indigenous Intellectuals. Durham and London: Duke UP.

BEJARANO, Sandra. 2015. “La Ley 1008, por el momento, seguirá sin modificaciones." La Prensa (La Paz) 12 de marzo 2015.

[http://www.laprensa.com.bo/diario/actualidad/pol\%C3\%ADtica/20150312 /la-ley-1008-por-el-momento-seguira-sin_65263_108414.html] downloaded June 10, 2015.

BEWLEY-TAYLOR and Martin Jelsma. 2011. Fifty Years of the 1961 Single Convention on Narcotic Drugs: A Reinterpretation. TNI. Series on Legislative Reform of Drug Policies 12. [http://www.tni.org/files/download/dlr12.pdf] downloaded July 10, 2015.

BOLIVIA.COM. 2002. "Diálogo de la coca vuelve a reunir a Goni y Evo." [http://www.bolivia.com/noticias/autonoticias/DetalleNoticia10209.asp] downloaded May 08, 2015.

BOLPRESS. 2006. "Evo pide racionalizar el cultivo de coca pero el embajador de EE.UU. no se contenta." [http://www.bolpress.com/art.php?Cod=2006013002] downloaded June 10, 2015.

CALIZAYA, Ernesto. 2012. "Brasil y EEUU firman acuerdos para lucha antidroga en Bolivia." La Razón (La Paz) 21 de enero 2012 [http://www.larazon.com/nacional/Brasil-EEUU-acuerdos-antidrogaBolivia_0_1545445503.html] downloaded June 15, 2015.

CANESSA, Andrew. 2014. "Conflict, claim and contradiction in the new 'indigenous' state of Bolivia." Critique of Anthropology 34.2 (June): 153-173. 
[http://coa.sagepub.com/content/34/2/153] downloaded December 15, 2015.

CIA (Central Intelligence Agency). 1986. "Bolivia: the impact of operation Blast Furnace." Classified CIA document approved for release in May 2008. [http://www.foia.cia.gov/sites/default/files/document_conversions/89801/ DOC_0000395412.pdf] downloaded November 15, 2015.

---. $\quad$ 1988. "Beyond Operation Blast Furnace. Bolivia's struggle against narcotics." Secret report approved for release in June 2003. [http://www.foia.cia.gov/sites/default/files/document_conversions/89801 /DOC_0001000220.pdf] downloaded November 19, 2015.

CONZELMAN, Caroline. 2007. "Yungas Coca Growers Seek Industrialization but Split on Legalization." [https://nacla.org/news/yungas-coca-growers-seekindustrialization-split-legalization] downloaded March 17, 2014.

DAHL, Fredrik. 2012. "Bolivia Defends Coca Consumption at U.N. meet." Reuters. [http://www.reuters.com/article/2012/03/13/us-drugs-un-boliviaidUSBRE82C02720120313] downloaded June 27, 2015.

DIAZ-COTTO, Juanita. 2007. "Latina Imprisonment and the Drug on War." Race Gender and Punishment. From Colonialism to the War on Terror. Mary Bosworth and J. Flavin, eds. New Brunswick, NJ: Rutgers. 186-195.

DURAND OCHOA, Ursula. 2014. The Political Empowerment of the Cocaleros of Bolivia and Peru. New York, NY: Palgrave Macmillan.

DUSSEL, Enrique D. 2012. "Transmodernity and Interculturality: An Interpretation from the Perspective of Philosophy of Liberation." Transmodernity: Journal of Peripheral Cultural Production of the Luso-Hispanic World 1(3): 28-59.

EJU!. 2011. "Oposición propone endurecer la Ley 1008, el MAS rechaza." [http://eju.tv/2011/04/legislativo-oposicin-propone-endurecer-la-leyantidroga-1008-el-mas-rechaza/] downloaded July 23, 2015.

ERBOL DIGITAL. 2014. "Silvia Rivera asegura que la derecha es Evo."

[http://www.erbol.com.bo/noticia/politica/06012014/silvia_rivera_asegura _que_la_derecha_es_el_evo] downloaded July 14, 2015.

ESTADO PLURINACIONAL DE BOLIVIA. 2007. Plan Nacional de Desarrollo. Decreto Supremo 29272.

FARTHING, Linda. 1997. "Social Impacts Associated with Antidrug Law 1008." Coca, Cocaine and the Bolivian Reality. Madeline B. Leóns and H. Sanabria, eds. Albany: State U of New York P. 253-270.

---. 2014. "Al ritmo de otro tambor. El control social comunitario del cultivo de la coca en Bolivia." Andean Information Network. [http://ainbolivia.org/2014/07/al-ritmo-de-otro-tambor] downloaded May 15, 2015. 
FARTHING, Linda and Kathryn Ledebur. 2015. Habeas Coca. Bolivia's Community Coca Control. New York: Open Society Foundations.

[https://www.opensocietyfoundations.org/sites/default/files/Bolivia\%20Re port-Habeas\%20Coca-US-07-06-2015-corr1.pdf] downloaded October 24, 2015.

GELLES, Paul. 1985. "Coca and Andean Culture: The New Dangers of an Old Debate." Cultural Survival Quarterly 9 (5): 20-23.

[https://www.culturalsurvival.org/ourpublications/csq/article/coca-andandean-culture-the-new-dangers-old-debate] downloaded August 15, 2015.

GIACOMAN, Diego. 2011. "Drug Policy and the Prison Situation in Bolivia." Systems Overload. Drug laws and prisons in Latin America. Pien Metaal and C. Youngers, eds. Amsterdam/Washington, D.C.: Transnational Institute /WOLA. 21-29.

[http://www.wola.org/sites/default/files/downloadable/Drug\%20Policy/20 11/TNIWOLA-Systems_Overload-def.pdf] downloaded December 13, 2015. GONZÁLEZ CASANOVA, Pablo. 2006. "El colonialismo interno." Sociología de la explotación. Buenos Aires: CLACSO. 185-205.

[http://bibliotecavirtual.clacso.org.ar/ar/libros/secret/gonzalez/colonia] downloaded April 08, 2015.

HASTERT, Dennis. 2002. "Honoring Former President Jorge Quiroga Ramirez of the Republic of Bolivia." US Government Publishing Office. Congressional Record 148.152: E2138-E2139. [https://www.gpo.gov/fdsys/pkg/CREC2002-11-22/pdf/CREC-2002-11-22-pt1-PgE2138-2.pdf] downloaded May 3, 2015.

HESSELROTH, Alba. 2004. "Struggles of Security in US Foreign Drug Policy Towards Andean Countries." Peace Conflict and Development 5. 2-29.

[http://www.brad.ac.uk/ssis/peace-conflict-and-development/issue5/StrugglesofSecurity.pdf] downloaded May 17, 2015.

HOWARD, Rosaleen. 2010. "Language, Signs, and the Performance of Power: The Discursive Struggle over Decolonization in the Bolivia of Evo Morales." Latin American Perspectives 37 (3): 176-194.

HUMAN RIGHTS WATCH. 1995. Bolivia: Human Rights Violations and the War on Drugs. [http://www.refworld.org/docid/3ae6a7e64.html] downloaded March 13, 2015.

ISIKOFF, Michael. 1990. "Bolivia Seeks \$150 Million Annually." The Washington Post.

[http://www.washingtonpost.com/archive/politics/1990/05/08/boliviaseeks-150-million-annually/8a3fc46c-8be5-43c5-b4bd-24b8e19244b8/] 
downloaded April 10, 2015.

JELSMA, Martin. 2011. "Lifting the ban on coca chewing. Bolivia's proposal to amend the 1961 Single Convention." TNI. Series on Legislative Reform of Drug Policies 11. [https://www.tni.org/files/download/dlr11.pdf] downloaded May 23, 2015.

JIMÉNEZ, Luz. 2014. "Indigenous Leaders and the Challenges of Decolonization in Bolivia." The Education of Indigenous Peoples in Latin America. Regina Cortina, ed. Tonawanda, NY: Multilingual Matters. 169-186.

KRAUL, Chris. 2009. "DEA presence ends in Bolivia." Los Angeles Times. [http://articles.latimes.com/2009/jan/30/world/fg-bolivia-dea30] downloaded May 12, 2015.

LA RAZÓN. 2012. "García Linera asegura que Bolivia se descolonizó económicamente."

[http://www.la-razon.com/economia/Garcia-Linera-Bolivia-descolonizoeconomicamente_0_1703829680.html] downloaded August 13, 2015.

LEDEBUR, Kathryn. 2002. "Coca and Conflict in the Chapare." Drug War Monitor WOLA Briefing Series 1 (1): 1-23.

[http://www.wola.org/publications/drug_war_monitor_vol_1_no_1] downloaded October 18, 2015.

---. $\quad$ 2005. "Bolivia: Clear Consequences." Drugs and Democracy in Latin America: The Impact of US Policy. Coletta A. Youngers and E. Rosin, eds. Boulder, CO.: Lynne Rienner Publisher. 151-155.

LEDEBUR, Kathryn and Coletta Youngers. 2013. "From Conflict to Collaboration: An Innovative Approach to Reducing Coca Cultivation in Bolivia." Stability: International Journal of Security and Development 2(1): 1-11. [http://dx.doi.org/10.5334/sta.aw] downloaded May 13, 2015.

LEFEBVRE, Stephan and Jeanette Bonifaz. 2014. "Lessons from Bolivia: Renationalizing the Hydrocarbon Industry." Open Democracy UK. [https://www.opendemocracy.net/ourkingdom/stephan-lefebvre-jeanettebonifaz/lessons-from-bolivia-renationalising-hydrocarbon-indust] downloaded April 27, 2015.

MANNING, Bayless. 1977. "The Congress, the Executive, and the Intermestic Affairs: three Proposals." Foreign Affairs 55. 306-322. [https://www.foreignaffairs.com/articles/1977-01-01/congress-executiveand-intermestic-affairs-three-proposals] downloaded April 14, 2015.

MARX, Gary. 1992. "Bolivia`s ‘Coca Diplomacy' Aims To Lift Ban.” Chicago Tribune. [http://articles.chicagotribune.com/1992-1206/news/9204210099_1_coca-eradication-bolivia-president-jaime-pazzamora] downloaded May 14, 2015. 
MEALLA, Luis. 2012a. "García: Descolonizar es construir hegemonía indígena en el Estado." La Razón (La Paz) 12 de octubre 2012 [http://www.larazon.com/nacional/Garcia-Descolonizar-construir-hegemoniaindigena_0_1704429594.html] downloaded April 17, 2015.

---. 2012b. "Gobierno busca industrializar la coca a través de tres proyectos." La Razón (La Paz) 27 de febrero 2012 [http://larazon.com/nacional/Gobierno-busca-industrializar-travesproyectos_0_1567643261.html] downloaded May 22, 2015.

MENDOZA, Luz. 2010. "Cocaleros aceptan negociar con el gobierno y piden que la reunión sea en Unduavi." Eju. [http://eju.tv/2010/10/cocaleros-aceptannegociar-con-el-gobierno-y-piden-que-la-reunin-sea-en-unduavi/] downloaded April 16, 2015.

MENZEL, Sewall H. 1996. Fire in the Andes: US Foreign Policy and Cocaine Politics in Bolivia and Peru. Lanham, MD.: UP of America.

METAAL, Pien. 2006. "Coca Yes, Cocaine. No? Legal Options for the Coca Leaf." Drugs and Conflict. Debate Papers 13. TNI.

---. 2010. "Bolivia in Urgent Need for a Drug Law Reform." TNI. Drugs and Democracy. [http://undrugcontrol.info/en/weblog/item/696-bolivia-inurgent-need-of-a-drug-law-reform] downloaded May 16, 2015.

MIGNOLO, Walter. 2000. Local Histories/Global Designs: Coloniality, Subaltern Knowledges, and Border Thinking. Princeton, NJ.: Princeton UP.

MUÑOZ-POGOSSIAN, Betilde. 2008. Electoral Rules and the Transformation of Bolivian Politics: the Rise of Evo Morales. New York: Palgrave Macmillan.

OEA/CIDH. 2013. Informe sobre el uso de la prisión preventiva en las Américas. [http://www.oas.org/es/cidh/ppl/informes/pdfs/informe-pp-2013-es.pdf] downloaded May 23, 2015.

PÁGINA 12. 2006. "Los discursos de Evo." [http://www.pagina12.com.ar/diario/especiales/18-62330-2006-0130.html] downloaded January 17, 2015.

PAZ ZAMORA, Jaime. 1992. Speech before the UN 47 th session General Assembly. Provisional verbatim record of the 9th meeting, New York. A-47-PV-9. [https://disarmamentlibrary.un.org/UNODA/Library.nsf/889f4ca5a12aff2c8525755c0052de6b/ef 9f7feb2914fdcf85257afd006d0306/\$FILE/A-44-PV11.pdf] downloaded January 17, 2015.

POP-ELECHES, Grigore. 2009. Crisis Politics: IMF Programs in Latin America and Eastern Europe. Princeton, N.J. /Woodstock, Oxfordshire: Princeton UP. 
POSTERO, Nancy. 2015. "El Pueblo Boliviano, de Composición Plural: A look at Plurinationalism in Bolivia." The promise and Perils of Populism: Global Perspectives. Carlos de la Torre, ed. Lexington, KY.: UP of Kentucky. 398425.

QUIJANO, Anibal. 2000. "Coloniality of Power, Eurocentrism, and Latin America." Nepantla: Views from South 1 (3): 533-580.

[http://www.unc.edu/ aescobar/wan/wanquijano.pdf ] downloaded January 20, 2015.

RADIO CEPRA. 2015. "Morales afirma que rescatar nuestra cultura es la mejor descolonización."

[http://www.radiocepra.com/index.php/noticias-del-occidente/3218morales-afirma-que-rescatar-nuestra-cultura-es-la-mejor-descolonizacion] downloaded Oct. 16, 2015.

REINAGA, Fausto. 2001 [1969]. La revolución india. La Paz: Ediciones Fundación Amáutica.

RIBANDO, Clare M. 2007. "Bolivia: Political and Economic Developments and the Relations with the United States." Congressional Research Service. Report for Congress. [https://www.fas.org/sgp/crs/row/RL32580.pdf] downloaded May 27, 2016

RIVERA CUSICANQUI, Silvia. 2010. Ch'ixinakax utxiwa: una reflexión sobre prácticas y discursos descolonizadores. Buenos Aires: Tinta Limón.

---. 2012. Violencias (re)encubiertas en Bolivia. Santander: Otramérica.

RUSSO, Philip A. and Patrick J. Haney. 2012. "Intermestic Policies and Homeland Security." The Domestic Sources of American Foreign Policy: Insights and Evidence. Eugene R. Wittkopf and J. McCormick, eds. Plymouth: Rowman \& Littlefield Publishers. 285-300.

SALAZAR ORTUÑO, Fernando B. 2008. De la coca al poder. Buenos Aires: CLACSO. [http://bibliotecavirtual.clacso.org.ar/ar/libros/clacso/crop/coca/] downloaded July 26, 2015.

SCHILLING-VACAFLOR, Almut. 2008. "Indigenous identities and politico-juridical demands of CSUTCB and CONAMAQ in the constitutional change process of Bolivia." T'inkazos 11 (23-24): 149-170.

[http://socialsciences.scielo.org/scielo.php?pid=S199074512008000100003\&script=sci_arttext] downloaded July 27, 2015.

STAVENHAGEN, Rodolfo. 1981. Between Underdevelopment and Revolution: A Latin American Perspective. New Dehli: Abhinav.

TAPIA, Luis “Una reflexión sobre la idea de Estado plurinacional." OSAL (CLACSO) VIII (22): 47-63. 
[http://bibliotecavirtual.clacso.org.ar/ar/libros/osal/osal22/D22Tapia.pdf] downloaded July 20, 2015.

THOUMI, Francisco, 2003. Illegal Drugs, Economy and Society in the Andes. Washington, D.C.: Woodrow Wilson Center Press.

TICONA, Esteban. 2010. "La producción del conocimiento descolonizador en contextos del colonialismo interno. El caso de Fausto Reinaga en QullasuyuBolivia." Revista Integra Educativa 3 (1): 37-48.

[http://www.scielo.org.bo/scielo.php?pid=S199740432010000100003\&script=sci_arttext] downloaded June 12, 2015.

TRANSNATIONAL INSTITUTE. 2008. "Letter by Evo Morales to UN Secretary General Ban Ki-moon."

[http://www.druglawreform.info/en/issues/unscheduling-the-cocaleaf/item/2623] downloaded May 26, 2015.

UNITED NATIONS. 2012. Depositary Notification. “United States of America: Objection to the Reservation Contained in the Communication by the Plurinational State of Bolivia. 3 July 2012." Reference:

C.N.361.2012.Treaties-VI.18.

[https://treaties.un.org/doc/Publication/CN/2012/CN.361.2012-Eng.pdf] downloaded March 17, 2014.

UNODC. United Nations Office on Drugs and Crime. 2012. Estado Plurinacional de Bolivia: Monitoreo de Cultivo de Coca 2011. [https://dl.dropboxusercontent.com/u/64663568/library/Bolivia-cocasurvey-spanish_2012.pdf] downloaded June 9, 2015.

---. $\quad$ 2015. Estado Plurinacional de Bolivia: Monitoreo de Cultivo de Coca 2014. [https://www.unodc.org/documents/bolivia/Bolivia_Informe_Monitoreo_C oca_2014.pdf] downloaded June 9, 2015.

US CENSUS BUREAU. 1978. World Population 1977: Recent Demographic Estimates for the Countries and Regions of the World. US Department of Commerce.

US CONGRESS. 1993. Alternative Coca Reduction Strategies in the Andean Region. Office of Technology Assessment. OTA-F-556. Washington, DC.: US Government Printing Office.

---. $\quad$ 1998. Presidential Determination No. 98-15. Certification for Major Illicit Drug Producing and Drug Transit Countries. Federal Register 63 (50).

---. 2002. Bureau of International Narcotics and Law Enforcement Affairs. 2002. South America: Bolivia (IV-6- IV10). International Narcotics Control Strategy Report for 2001.

[http://www.state.gov/documents/organization/8695.pdf] downloaded May 12, 2015. 
---. 2008. Drug and Chemical Control. International Narcotics Control Strategy Report. I. [http://www.state.gov/documents/organization/102583.pdf] downloaded May 18, 2015.

VANAIK, Achin. 2005. "US dominance and diplomatic choices in developing nations." Diplomacy and Developing Nations: Post-Cold War foreign policymaking structures and processes. Justin Robertson and Maurice A. East, eds. Abingdon, Oxon/New York: Routledge.

ZAVALETA MERCADO, René. 2008 [1986]. Lo nacional-popular en Bolivia. La Paz: Plural Editores.

\section{$(\mathrm{cc}) \mathrm{BY}$}

ULIS D-Serle $\begin{aligned} & \text { This journal is published by the University Library System of the } \\ & \text { University of Pittsburgh as part of its D-Scribe Digital Publishing } \\ & \text { Program, and is cosponsored by the University of Pittsburgh Press. }\end{aligned}$

New articles in this journal are licensed under a Creative Commons Attribution 4.0 United States License. 